\title{
Perspectives on gender parity in bioanalysis: an interview with Shane Needham
}

Shane Needham*,1

${ }^{1}$ Alturas Analytics, Inc., 1324 Alturas Drive, Moscow, ID 83843, USA

*Author for correspondence: sneedham@alturasanalytics.com

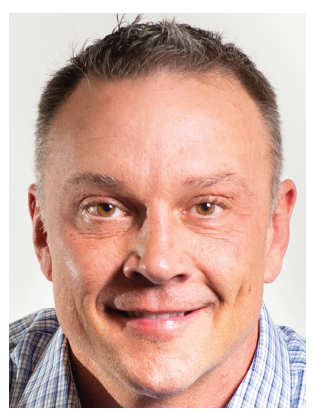

\section{Biography:}

Dr Shane Needham received his BS degree in chemistry from Washington State University and his PhD in chemistry from the University of Rhode Island. Dr Needham is Co-Founder and Chief Scientific Officer of Alturas Analytics, Inc. Dr Needham manages all scientific aspects of the HPLC/MS/MS bioanalytical contract laboratory at Alturas Analytics, Inc. Currently, Dr Needham's work is focused on the development and validation of assays for the determination of therapeutic agents and biomarkers from biological matrices. His laboratory leads in the area of dried blood spot analysis, microflow HPLC-MS/MS and LC-MS/MS of large molecules (Antibody Drug Conjugates, Biomarkers, New Biological Entities, etc.) to support Drug Metabolism and Pharmacokinetics research.

Accepted for publication: 5 March 2019; Published online: 18 April 2019

\section{What advice would you give to young women hoping to embark on a career in the field?}

The advice I would give anyone looking to grow in a career is, get a good education, set high goals, give your best effort, seek out advice from mentors, set no limits on yourself and keep learning every day. Seek to improve yourself every day - in science and your career and in your personal life.

\section{How important it is to have a short- and long-term goals in your career?}

Short- and long-term goals are important as our careers, industry and personal life change. My advice for short-term goals would be to focus on the day-to-day tasks and operations knowing that your personal needs and family must be a priority. Long-term goals are similar with the personal life first motto and how will my career, management, location of career and quality of life influence my personal/family needs. I think the person is rare who would say, "I am glad I sacrificed so much to have a good career at the expense of my personal needs, family and relationships." Life is not a 'balance' in this way - relationships should come first. Relationships bring true meaning to our lives and give us true fulfillment.

\section{What do you see as being the most effective solution to getting more women involved in STEM careers?}

Passionate and charismatic leaders should reach out to the community to promote science and encourage diversity at a young age. Give the vision to everyone that they can imagine themselves in that career. Make it fun! Make it exciting! Make it interactive! This is what people desire. To have fun! Make a difference! Have a purpose! Leaders should work with youth at schools, universities, summer programs and clubs to engage them to desire a Science, Technology, Engineering and Mathematics (STEM) career.

The manner of recruitment (how we advertise, who we advertise to, promotion of organizations, etc.) of women in biosciences should also accurately reflect the fact that women represent a significant percentage of scientists working in the field. 
If you were asked to create a specific framework in your business to encourage more gender parity, how will you do that?

We focus on competence and results not gender. More than $75 \%$ of our scientific staff are women. By focusing on competence, we encourage equality at all levels. The culture needs to create a sense of belonging for everyone including being a part of 'something bigger than yourself' to encourage parity at all levels. Once there is a bigger purpose, it minimizes any apparent inequalities.

\section{How do you think the scientific field could inspire the next generation of scientists to advocate gender parity?}

Find thoughtful leaders who are passionate about their STEM careers and reach out to communities to encourage science. It is also important to correct the misconception that women are not making significant progress in choosing and establishing careers in the scientific fields (particularly in biosciences). In fact, in some areas of STEM women are outnumbering men in their respective areas. So the effort to increase the presence of STEM fields should include the fact that they will not be one of a few, but rather part of a larger and currently successful movement toward parity. Our lab is reflective of the national trends with women in professional positions outnumbering men by 3:1. In fact, a recent study by the NSF found that the only STEM areas where men outnumber women is in computer science and engineering (program broadcast by PBS from statistics from the National Science Foundation, 17 April 2015, 'Why the STEM gender gap is overblown').

\section{Disclaimer}

The opinions expressed in this interview are those of the interviewee and do not necessarily reflect the views of Future Science Group.

\section{Financial \& competing interests disclosure}

The author has no relevant affiliations or financial involvement with any organization or entity with a financial interest in or financial conflict with the subject matter or materials discussed in the manuscript. This includes employment, consultancies, honoraria, stock ownership or options, expert testimony, grants or patents received or pending, or royalties.

No writing assistance was utilized in the production of this manuscript. 